\title{
PERILAKU CARING MAHASISWA PROGRAM STUDI SARJANA KEPERAWATAN STIKES HAFSHAWATY PESANTREN ZAINUL HASAN
}

\author{
Ana Fitria Nusantara ${ }^{1)}$, Shinta Wahyusari ${ }^{2}$ \\ Program Studi Sarjana Keperawatan, Stikes Hafshawaty Pesantren Zainul Hasan \\ email: anafitriaachmad@gmail.com
}

\begin{abstract}
ABSTRAK
Caring dalam keperawatan merupakan hal yang paling mendasar dan harus diajarkan sejak dini. Caring yang diajarkan dan ditanamkan sejak dini yaitu sejak mahasiswa berada di tingkat satu harapannya ketika mahasiswa berada pada tahap pembelajaran klinik mahasiswa dapat mengaplikasikan atau melakukan asuhan keperawatan dengan jiwa caring. Tujuan dari penelitian ini adalah untuk mengetahui perilaku Caring mahasiswa. Desain kualitatif digunakan pada penelitian ini dengan pendekatan phenomenology hermeneutic. Data dikumpulkan dengan tehnik wawancara tidak terstruktur kemudian dianalisis dengan tehnik Van Manen. Hasil penelitian menunjukkan bahwa pengetahuan mahasiswa tentang caring terbatas pada definisi caring itu sendiri, sementara perilaku caring mahasiswa menunjukkan perbedaan antara mahasiswa tingkat dua, tiga dan empat. Penelitian ini memberikan bukti bahwa semakin tinggi strata pendidikan dan semakin banyak pengalaman praktik yang sudah dilalui sangat berpengaruh pada perilaku caring mahasisawa. Hal ini sangat bermanfaat dalam rangka meningkatkan pelayanan keperawatan pada pasien.
\end{abstract}

Kata kunci: perilaku caring, mahasiswa keperawatan

\begin{abstract}
Caring in nursing is the most basic thing and must be taught early. Caring must taught and instilled early, since students are at the first level, hopely when students are at the clinical learning stage, they can apply or treath the patients with nursing care. The purpose of this study was to determine the behavior of student caring. The qualitative design was used in this study with a phenomenology hermeneutic approach. Data collected with unstructured interview techniques were then analyzed with Van Manen techniques. The results showed that the students' knowledge about caring was limited to the definition of caring itself, while the caring behavior of students showed the difference between second, third and fourth level students. This study provides evidence that the higher level of education and the more practical experience that has been traversed is very influential on student caring behavior. This is very useful in order to improve nursing services for patients.
\end{abstract}

Keywords: caring behavior, nursing students

\section{PENDAHULUAN}

Caring adalah inti dari praktik keperawatan yang harus tumbuh dan berasal dari dalam individu sendiri (purba, 2013). Caring merupakan fenomena umum yang berhubungan dengan cara berfikir individu, berperasaan serta bersikap ketika melakukan interaksi dengan orang lain. Tidak mudah untuk membentuk perilaku caring, perlu dilakukan penguatan dan dukungan sejak dini yaitu pada tahap kuliah. Faktor yang mempengaruhi perilaku caring mahasiswa, salah satu 
diantaranya adalah faktor pengalaman (Yulianti, 2015).

Hasil studi pendahuluan yang dilakukan pada 6 mahasiswa pada bulan Desember 2017 didapatkan fenomena caring mahasiswa pada pembelajaran klinik tahap pertama yaitu mahasiswa melakukan komunikasi dengan pasien ketika melakukan pengkajian awal, pemeriksaan fisik dan ketika akan melakukan tindakan keperawatan. Komunikasi yang dilakukan cenderung pada hal-hal berdasarkan kepentingan mahasiswa dalam mendapatkan data untuk menyusun laporan praktik pembelajaran klinik.

Permasalahan tersebut tidak dapat kita abaikan karena sikap profesional perawat dalam bekerja dapat berpengaruh terhadap kesehatan pasien. Penurunan kualitas caring dapat terjadi karena kurangnya kesadaran perawat akan pentingnya perilaku caring dalam melakukan asuhan keperawatan (Fahmi, 2010). Perilaku caring perawat dalam tatanan pelayanan kesehatan dapat berpengaruh pada keadaan pasien, yaitu dapat membantu kesembuhan pasien. Sikap peduli dan komunikasi sangat berhubungan dengan keadaan pasien, tetapi hampir tidak pernah terlihat selama proses perawatan berlangsung (Liu et al., 2010)

\section{METODE PENELITIAN}

Metode yang digunakan adalah desain penelitian kualitatif dengan pendekatan fenomenologi hermenuetik. Data dikumpulkan dengan tehnik wawancara terstruktur kepada 5 partisipan yang merupakan mahasiswa tingkat dua, tiga dan empat. Wawancara dilakukan dengan waktu 15-20 menit dan direkam dengan alat perekam. Kemudian hasil wawancara ditranskripkan dan dianalisis menggunakan metode Van Manen untuk mendapatkan tema.

\section{HASIL DAN PEMBAHASAN}

\section{Hasil Penelitian}

Penelitian ini menghasilkan 4 tema dan 6 sub tema yang masing-masing terbagi sesuai dua tujuan khusus. Penyajian tema sesuai tujuan khusus pada penelitian ini, sebagaimana berikut :

\section{a. Karakteristik Partisipan}

Tabel Distribusi Partisipan, meliputi Usia Partisipan, Jenis Kelamin dan Tingkat semester.

\begin{tabular}{ccc}
\hline Variabel & $\mathrm{n}$ & $\%$ \\
\hline Usia & 2 & $40 \%$ \\
- 19 Tahun & 2 & $40 \%$ \\
- 20 Tahun & 1 & $20 \%$ \\
- 21 Tahun & & \\
& & \\
Jenis kelamin & 2 & $40 \%$ \\
- Laki-laki & 3 & $60 \%$ \\
- Perempuan & & \\
Tingkat Semester & & \\
- Tingkat 2 & 2 & $40 \%$ \\
- Tingkat 3 & 2 & $40 \%$ \\
- Tingkat 4 & 1 & $20 \%$ \\
\hline
\end{tabular}

\section{b. Gambaran Pengetahuan Mahasiswa tentang Caring}

Tema1: gambaran pengertian caring dengan 3 sub tema

Sub tema pertama: ramah

Para partisipan (mahasiswa) menggambarkan bahwa caring adalah sikap yang baik pada pasien yang ditunjukkan dengan cara menyapa dan mengajak pasien berbicara dengan wajah yang damai dan senyum yang selalu menyertai.

Sub tema kedua: sabar

Para partisipan (mahasiswa) memaparkan bahwa caring adalah sikap menerima pasien apa adanya dalam menghadapi pasien dengan berbagai macam karakter yang ditunjukkan dengan cara tetap tersenyum walaupun pasien menolak dengan tidak baik ketika partisipan datang dan mencoba terus sampai pasien menjadi kooperatif dan menerima kehadiran partisipan.

Sub tema ketiga: memberikan perhatian

Partisipan memaparkan bahwa caring adalah perilaku yang dilakukan pada pasien dengan selalu mendengarkan cerita pasien, 
dan peduli dengan apa yang pasien rasakan maupun yang dialami. partisipan membiarkan pasien bercerita tentang masalah apa saja termasuk masalah pribadi yang tidak ada kaitan dengan penyakitnya, hal ini dilakukan untuk menujukkan kepedulian terhadap apa yang terjadi pada pasien.

\section{c. Perilaku Caring Mahasiswa}

Tema 1: melakukan pengkajian dengan 2 sub tema

Sub tema pertama: menanyakan keluhan dan riwayat penyakit

Dari hasil wawancara didapatkan bahwa para partisipan menanyakan tentang masalah pasien seperti apa yang dirasakan saat ini, kenapa bisa mengalami keadaan tersebut, dan kebiasaan apa yang dilakukan pasien di rumah yang mendukung keadaannya saat ini.

Sub tema kedua: berorientasi pada kepentingan diri sendiri

Partisipan memaparkan bahwa menggunakan format pengkajian dari institusi sebagai bahan untuk pertanyaan pada pasien, dan apabila data sudah terkumpul semua maka partisipan tidak menemui pasien lagi selain untuk melakukan tindakan rutin dari ruangan praktik.

Tema 2: mendampingi pasien

Partisipan (mahasiswa) memaparkan bahwa perilaku caring dapat ditunjukkan dengan cara selalu ada untuk pasien dalam keadaan apapun sampai pasien pulang atau meninggal. Partisipan menyampaikan bahwa pasien di rumah sakit hanya ingin diperhatikan oleh orang-orang disekitar dan maka dari itu perawat harus selalu ada untuk pasien dalam keadaan apapun, misalnya partisipan mendampingi pasien yang akan dilakukan prosedur tertentu dan memberikan dukungan serta motivasi.

Tema 3: Memberikan solusi dengan pengetahuan

Sub tema pertama: Pendidikan kesehatan

Partisipan (mahasiswa) memaparkan bahwa caring dapat ditunjukkan dengan cara memberikan tambahan pengetahuan pada pasien khususnya tentang hal-hal yang berkaitan dengan penyakit yang diderita. Seperti menjelaskan pada pasien tentang penyakitnya, mulai dari penyebab, faktor yang mempercepat penyembuhan, faktor yang dapat menghambat proses kesembuhan, cara untuk sembuh, kompklikasi yang bisa terjadi dan prognosis penyakit. Termasuk selalu menjelaskan maksud dan tujuan dari setiap prosedur yang akan dilakukan pada pasien. Hal tersebut dilakukan untuk membuat pasien merasa aman dan nyaman dalam menjalani perawatan.

Sub tema kedua: meningkatkan self care

Partisipan (mahasiswa) memaparkan bahwa caring dapat ditunjukkan dengan cara menjelaskan pada pasien tentang bagaimana cara untuk survive terhadap penyakitnya dengan cara memaksimalkan kemampuan yang dimiliki untuk merawat diri sendiri tanpa tergantung pada keluarga dan petugas kesehatan serta mengontrol diri dalam mempercepat kesembuhannya. Misalnya: teratur mengkonsumsi obat oral sesuai dosis yang ditetapkan, makan teratur tanpa diingatkan ketika waktu makan tiba, tidak mengkonsumsi makanan atau minuman yang dilarang yang dapat memperparah penyakitnya, tidak melakukan hal hal yang dapat memperberat penyakitnya atau yang dapat menimbulkan komplikasi.

\section{Pembahasan}

\section{Gambaran Pengetahuan Mahasiswa tentang Caring}

Berdasarkan pada hasil wawancara dan hasil analisis tema, peneliti menemukan 1 tema, yaitu: gambaran pengertian caring, dengan 2 sub tema, yaitu: ramah, sabar, dan memberikan perhatian. Hal ini ditunjukkan dengan beberapa pernyataan dan jawaban partisipan.

Tema: gambaran pengertian caring Sub tema pertama: ramah

Caring adalah merupakan praktik tindakan keperawatan yang dapat dilakukan dengan cara tindakan proses keperawatan yang bertujuan untuk meningkatkan kesembuhan, yang dapat 
berupa pemberian perhatian pada pasien, fokus dalam melakukan perawatan pasien, saling menghormati, selalu mendampingi klien selama proses keperawatan berlangsung, memberikan pujian atas capaian perawatan pasien, memberikan tambahan pengetahuan tentang penyakit pasien serta sikap yang baik dalam perawatan pasien. (Dwidiyanti, 2007 dalam Tiara \& Lestari, 2013). Caring merupakan pengetahuan tentang rasa kemanusiaan dan merupakan inti dari praktik keperawatan yang beretika dan filosofis.

Perilaku caring dipengaruhi oleh beberapa faktor yaitu faktor yang berasal dari individu itu sendiri, keadaan psikologis, organisasi, faktor usia yang berhubungan dengan sikap dewasa seseorang dan juga faktor dari strata pendidikan (Zees, 2011). Caring dapat juga mempengaruhi kinerja perawat dalam melakukan proses keperawatan. Faktor usia yang masih belia dapat mempengaruhi sikap seseorang dalam berperilaku. Sementara strata pendidikan yang rendah dapat berpengaruh terhadap kinerja perawat.

Caring tidak hanya secara perilaku, akan tetapi caring adalah sebuah cara yang memiliki sebuah arti dan dapat memotivasi tindakan. Perilaku yang baik (caring) dan disertai keramah dalam berinteraksi dengan pasien dapat menyebabkan terbentuknya self efficacy pada diri pasien. Dengan bertambahnya usia menjadi dewasa dan diiringi dengan tingkat pendidikan yang baik maka dapat meningkatkan kemampuan seseorang dalam mengimplementasikan sebuah teori.

Sub tema kedua : sabar

Perilaku caring perawat sangat dibutuhkan dalam pelayanan tindakan keperawatan, sehingga dapat menunjang tingkat kepuasan pasien. (Sukesi, 2013). Hal tersebut dapat diwujudkan dengan perilaku perawat yang menerima keadaan pasien apa adanya dan melakukan perawatan dengan penuh kesabaran dan semaksimal mungkin. Pasien yang mendapatkan perawatan dengan perilaku caring yang baik menunjukkan tingkat kecemasan yang ringan. Pelayanan caring akan memberikan rasa tenang pada pasien dalam menjalani perawatan yang ditunjang dengan keadaan psikologis yang baik. Selain itu caring perawat dapat meningkatkan kepuasan pasien terhadap pelayanan keperawatan.

Seorang perawat harus memiliki perilaku caring dalam praktik keperawatan terhadap pasien, karena hubungan yang baik antara pemberi pelayanan kesehatan dengan penerima pelayanan merupakan faktor penting yang mempengaruhi terjadinya kepuasan dan kesembuhan pasien (Nursalam, 2011).

Sub tema ketiga: memberikan perhatian

Caring dapat ditunjukkan melalui tingkah laku seperti: menjadi pendengar yang baik bagi klien, memberikan perhatian kepada klien, menghargai klien dengan menunjukkan komitmennya untuk mengerti, menerima klien dan meningkatkan kemampuan klien untuk bertanggung jawab atas dirinya sehingga identitas diri klien meningkat. Sikap caring perawat akan membantu klien untuk memahami masalah yang dihadapinya, sehingga penempatan perilaku caring sebagai dasar dalam praktik keperawatan merupakan tiang utama yang harus di implementasikan dalam merapkan asuhan keperawatan (Purba, 2013).

Caring dalam keperawatan menurut Kozier \& Erb's1 adalah hal yang sangat mendasar, yang mana caring adalah jantung profesi, artinya sebagai komponen dasar dan unik dalam keperawatan. Caring mengandung tiga hal yang tidak dapat dipisahkan yaitu perhatian, tanggung jawab dan dilakukan dengan ikhlas. caring dapat ditunjukkan melalui tingkah laku seperti: menjadi pendengar yang baik bagi klien, menmberikan perhatian kepada klien, dan menghargai klien .

Standar Asuhan Keperawatan yang berkualitas seharusnya dapat diberikan oleh perawat maupun mahasiswa keperawatan yang sedang melaksanakan praktik klinik. Bila mahasiswa keperawatan telah memahami dan menjiwai secara mendalam tentang caring dalam asuhan keperawatan, maka kualitas hidup dan derajat kesehatan pasien dapat 
tercapai dengan baik dan diiringi dengan kepuasan pasien terhadap perawatan yang diberikan.

Pada penelitian ini didapatkan perbedaan pada pengetahuan mahasiswa setiap tingkat, yaitu: pada mahasiswa tingkat dua pengetahuan caring berfokus pada sikap ramah dalam berinteraksi dengan pasien. Pada mahasiswa tingkat tiga pemahaman tentang caring lebih menekankan pada kesabaran dalam menghadapi sikap pasien. Sedangkan pada mahasiswa tingkat empat pemahaman caring menekankan pada kesetiaan dalam mendampingi pasien dengan selalu ada untuk pasien.

\section{Perilaku Caring Mahasiswa}

Tema 1: melakukan pengkajian

Sub tema pertama : menanyakan keluhan dan riwayat pasien

Perilaku caring mahasiswa ditunjukkan dengan cara melakukan pengkajian sesuai target kompetensi yang harus dicapai oleh mahasiswa. pada saat praktik klinik, mahasiswa mengalami suatu kesulitan untuk berkomunikasi dengan pasien karena mahasiswa takut melakukan suatu kesalahan dalam menyampaikan suatu hal, sehingga komunikasi yang dilakukan mahasiswa hanya pada saat mahasiswa membantu kegiatan rutin pasien saja. Hal ini membuktikan bahwa mahasiswa tidak memiliki keberanian dalam menjalin komunikasi dengan pasien sehingga responden tidak menunjukkan perilaku caring kepada pasien. Job design mahasiswa berpengaruh dalam pembentukan perilaku caring mahasiswa. Perilaku caring mahasiswa berpengaruh dalam pencapaian kompetensi mahasiswa.

Perilaku caring perawat di rumah sakit berdampak pada keadaan pasien, sehingga dapat membantu pasien untuk bisa sembuh. Kategori faktor dari kepedulian dan komunikasi merupakan hal yang paling signifikan berhubungan kuat dengan keadaan pasien, tetapi jarang ditunjukkan selama melakukan perawatan pada pasien (Liu et al., 2010). Berdasarkan penelitian Laila (2011) didapatkan hasil bahwa sebagian besar pasien tidak puas terhadap perilaku caring perawat dan menilai perilaku caring perawat sangat kurang.

Mahasiswa yang sedang melakukan praktik klinik adalah mahasiswa yang sedang mengaplikasikan ilmu yang diperoleh di akademik, salah satunya dalam berperilaku caring, dituntun untuk bisa memiliki perhatian, tanggung jawab, dan dilakukan dengan ikhlas. Memberikan asuhan (caring) secara sederhana tidak hanya sebuah perasaan emosional atau tingkah laku sederhana, karena caring merupakan kepedulian untuk mencapai perawatan yang lebih baik (Feizal, 2012).

Tema 2: mendampingi pasien

Perawat memerlukan kemampuan khusus saat melayani orang atau pasien yang sedang menderita sakit. Kemampuan khusus tersebut mencakup keterampilan intelektual, teknikal, dan interpersonal yang tercermin dalam perilaku caring

Berdasarkan hal tersebut dapat disimpulkan bahwa, caring bukan sematamata perilaku. Sikap caring dalam memberikan asuhan keperawatan, perawat menggunakan keahlian dengan kata-kata yang lemah lembut, sentuhan, memberikan harapan, selalu berada di samping klien, dan bersikap sebagai media pemberi asuhan.

Selalu ada untuk pasien dalam keadaan apapun serta selalu ada disamping pasien khususnya pada keadaan dimana pasien sedang menderita karena menahan sakit dapat memberikan semangat dan dukungan secara psikologis, hal tersebut dapat mempercepat proses penyembuhan bagi pasien.

Tema 3: memberikan solusi dengan pengetahuan

Sub tema pertama: pendidikan kesehatan

Upaya peningkatan perilaku caring dapat dilakukan dengan pendekatan individu, psikologi dan organisasi. Pendekatan individu dapat dilakukan dengan peningkatan pengetahuan dan keterampilan caring dengan pelatihan, seminar, maupun peningkatan pendidikan formal (Indrastuti. 2010).

Praktik caring menurut AACN yaitu menciptakan lingkungan yang mendukung 
caring (misalnya manajemen nyeri, pasien safety, pelaksanaan komunikasi terapeutik), mendukung pelaksanaan terapi komplementer, memfasilitasi pengembangan tim kesehatan tentang praktik caring melalui role model, pelatihan atau mentoring, mengkomunikasikan kebutuhan pasien dan keluarganya kepada tim kesehatan yang lain (ACNP, 2014).

Semakin tinggi tingkat pendidikan seseorang maka semakin baik juga pemahaman akan perilaku caring yang dapat ditunjukkan dengan kemampuan dalam memberikan pendidikan kesehatan pada pasien dalam rangka mencapai tujuan kesehatan maksimal pasien. Caring sebagai elemen penting dari keperawatan dan diterima secara luas di kalangan keperawatan. Pendekatan ini diyakini untuk meningkatkan kesehatan dan kesejahteraan pasien dan untuk memfasilitasi promosi kesehatan.

Sub tema kedua : meningkatkan self care

$$
\text { Sebagai seorang perawat, }
$$
kemampuan care dan cure harus dipadukan secara seimbang sehingga menghasilkan asuhan keperawatan yang optimal untuk klien. Selain itu, dapat juga dilihat dari intervensinya. Intervensi keperawatan (caring) yaitu membantu klien memenuhi masalah klien baik fisik, psikologis, sosial, dan spiritual dengan tindakan keperawatan yang meliputi intervensi keperawatan, observasi, pendidikan kesehatan, dan konseling.

Intervensi keperawatan dapat dilakukan secara aktif dan pasif sesuai dengan keadaan pasien. Intervensi keperawatan secara aktif dilakukan dengan melibatkan pasien dalam perawatan dengan cara memaksimalkan kemampuan yang dimiliki oleh pasien dalam rangka meningkatkan kemandirian pasien.

Pasien yang memiliki motivasi yang tinggi untuk sembuh dan ditunjang dengan support sistem yang baik dari sekitar termasuk perawat sebagai petugas kesehatan dapat meningkatkan kemandirian dan kemampuan pasien dalam merawat diri sendiri sebagai bekal perawatan di rumah.

Perilaku caring mahasiswa menunjukkan perbedaan yang jelas pada masing-masing tingkat, yaitu pada mahasiswa tingkat 2 perilaku caring diaplikasikan dengan berorientasi pada kepentingan penugasan dari institusi. Mahasiswa melakukan interaksi dengan pasien sesuai tugas yang menjadi target kompetensi seperti melakukan pengkajian dan intervensi keperawatan, setelah target tercapai mahasiswa menghentikan interaksi dengan pasien.

Pada mahasiswa tingkat dua perilaku caring mengedepankan cara pendekatan interpersonal seperti mengajak pasien membicarakan masalah pribadi, mendengarkan pasien curhat tentang masalah pribadi serta memberikan respon yang cenderung mendukung opini dan sikap pasien. Hal tersebut dilakukan karena mahasiswa menginginkan pasien percaya dengan sepenuh hati bahwa keberadaannya adalah untuk mendukung pasien. Sikap ini menjadi tidak objektif dan keluar dari konsep caring yang sebenarnya.

Sedangkan pada mahasiswa tingkat empat perilaku caring berfokus pada ketulusan mendampingi pasien dalam menghadapi penyakit yang dilakukan secara profesional yaitu dengan meningkatkan pengetahuan pasien dengan pemberian health education yang dibutuhkankan oleh pasien dan bisa dilakukan oleh pasien untuk meningkatkan status kesehatan dengan cara mampu merawat diri sendiri.

Caring merupakan tindakan keperawatan yang didasari oleh keinginan untuk mengerti, menolong dan mengurangi penderitaan pasien dengan melakukan tindakan yang terbaik bagi kesehatan pasien, berdasarkan nilai kebaikan untuk meningkatkan kepuasan serta memandirikan pasien. Kemampuan perilaku caring tersebut hanya dapat dilakukan oleh seseorang yang memiliki kecerdasan emosional (Ridwan, 2017).

Pendidikan dan pelatihan sangat mempengaruhi kecerdasan emosional individu karena kecerdasan emosional seseorang bukan merupakan potensi yang dibawa sejak lahir tetapi merupakan sesuatu yang dapat dipelajari. Oleh karena itu diperlukan peningkatan fokus pendidikan sehingga muncul komitmen untuk mempertahankan caring sebagai nilai sentral (Livianita. 2015). Diharapkan 
dengan didapatkannya tahap pembelajaran klinik sejak dini yaitu pada semester III maka semakin naik tingkat atau semester diharapkan perilaku caring mahasiswa juga semakin baik.

Temuan menunjukkan bahwa semakin tinggi tingkat pengetahuan dan pengalaman yang dimiliki oleh mahasiswa maka semakin baik pula pemahaman dan perilaku caring yang diberikan pada pasien.

\section{KESIMPULAN DAN SARAN}

\section{Kesimpulan}

Berdasarkan hasil penelitian yang dilaksanakan, maka dapat disimpulkan bahwa gambaran pengetahuan mahasiswa

\section{REFERENSI}

ACNP. (2014). The Role of the Acute Care Nurse Practitioner in the Implementation of the Commission on Cancer's Standards on Palliative Care. Clinical Journal of Oncology Nursing. Vol. 18, p39-44. 6p

Fahmi. (2010). Hubungan Antara Persepsi Ibu Tentang Perilaku Caring Perawat dengan Tingkat Kepuasan Ibu dengan Anak yang Dirawat di RSUD Fr. Moewardi Surakarta. UMS. Skripsi. Eprints.ums.ac.id. Diakses tanggal 2 Februari 2018.

Feizal, M.G. 2012. Perbedaan Perilaku Caring Antara Mahasiswa Profesi Ners LakiLaki dan Perempuan Jurusan Keperawatan FKIK Universitas Jenderal Soedirman. Tesis. Universitas Jenderal Soedirman. Purwokerto. Retrieved from:http://keperawatan.unsoed.ac.id..

Diakses tanggal 16 Juli 2017

Indrastuti, Y. (2010). Analisa Hubungan Perilaku Caring dan Motivasi dengan Kinerja Perawat Pelaksana Menerapkan Prinsip Etik Keperawatan Dalam Asuhan Keperawatan di RSUD Sragen. Tesis. FIK-UI.

Laila, Hafsyah. (2011). Hubungan Perilaku Caring yang Dilakukan Perawat Dengan Tingkat Kepuasan Klien Di Ruangan Penyakit Dalam RSUD tentang caring terbatas pada definisi caring saja, sedangkan perilaku caring mahasiswa menunjukkan perbedaan pada mahasiswa tingkat 2, 3 dan 4.

\section{Saran}

Diperlukan penambahan keilmuan tentang caring pada tahap akademik sehingga mahasiswa menjadi lebih siap ketika praktik di lahan, diperlukan pendidikan dan latihan yang terus-menerus kepada mahasiswa agar mereka menjadi terbiasa dalam berperilaku caring serta perlunya penelitian lebih lanjut tentang faktor-faktor yang dapat mempengaruhi kemampuan mahasiswa dalam mengaplikasikan teori caring.

Pariaman. http:// repository. unand.ac.id/17991/1/penelitian.

Liu, S.S. et al. (2010). The Impact Of Caring Behaviours On Patient Loyalty. Journal Of Emergency Nursing. St Louis. 10.1016. j.jen.2009.05.001

Livianita, Frieska. (2015). Hubungan Kecerdasan Emosional Perawat dengan Perilaku Caring Perawat Di Rumah Sakit Petala Bumi. UIN Sultan Syarif Kasim Riau. Skripsi. Retrieved from: repositori uin-suska. ac.id. Diakses tanggal 11 Januari 2018.

Nursalam. (2011). Manajemen Keperawatan: Aplikasi dalam Praktek Keperawatan Profesional. Edisi 3. Jakarta: Salemba Medika.

Purba M M., Emilia O., Rahayu G R. (2013). Pengaruh Pelatihan Caring terhadap Perilaku Memberikan Asuhan Keperawatan pada Mahasiswa saat Rotasi Klinik di Politeknik Depkes Palangka Raya. Jurnal Pendidikan Kedokteran Indonesia (The Indonesian Journal of Medical Education). Volume 2, No. 2

Ridwan. (2017). Hubungan Kecerdasan Emosional Perawat dengan Perilaku Caring Perawat di Ruang Rawat Inap RSUD Senopati Bantul. Skripsi. Retrieved from: repositori unjaya.ac.id. Diakses tanggal 11 Januari 2018. 
Saroh. (2017). Gambaran Kepuasan Mahasiswa Sarjana Keperawatan terhadap Pembelajaran Klinik Tahap Akademik. Departemen Ilmu Keperawatan FK Universitas Diponegoro Semarang. Thesis. Eprints.undip. ac. id. Diakses tanggal 2 Februari 2018.

Sukesi. (2013). Upaya Peningkatan Cring Perawat Terhadap Kepuasan Pasien di Ruang Rawat Inap RS Permata Medika Semarang. Jurnal Managemen Keperawatan . Volume 1, No. 1, Mei $2013 ; 15-24$

Tiara dan Lestari A. (2013). Perilaku Caring Perawat Dalam Meningkatkan Kepuasan Pasien Rawat Inap. Jurnal Keperawatan, Volume IX, No. 2
Yulianti, Eka., Agustina H R., Komariah M. (2015). Hubungan Faktorfaktor yang Mempengaruhi Sikap Caring pada Mahasiswa Fakultas Ilmu Keperawatan UNPAD. Fakultas Ilmu Keperawatan Universitas Padjajaran Bandung Jawa Barat.

Zees, F. (2011). Analisis Faktor Budaya Organisasi yang Berhubungan dengan Perilaku Caring Perawat Pelaksana di Ruang Rawat Inap RSUD Prof. Dr. H. Aloesi Saboe Kota Gorontalo. Tesis. Fakultas Ilmu Keperawatan: Universitas Indonesia. 